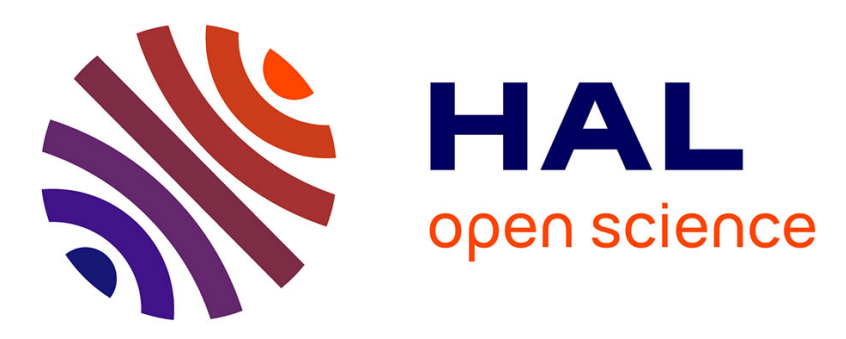

\title{
When instability increases the effectiveness of aid projects
}

Patrick Guillaumont, Rachid Laajaj

\section{To cite this version:}

Patrick Guillaumont, Rachid Laajaj. When instability increases the effectiveness of aid projects. 2011. halshs-00557176

\section{HAL Id: halshs-00557176 \\ https://shs.hal.science/halshs-00557176}

Preprint submitted on 18 Jan 2011

HAL is a multi-disciplinary open access archive for the deposit and dissemination of scientific research documents, whether they are published or not. The documents may come from teaching and research institutions in France or abroad, or from public or private research centers.
L'archive ouverte pluridisciplinaire HAL, est destinée au dépôt et à la diffusion de documents scientifiques de niveau recherche, publiés ou non, émanant des établissements d'enseignement et de recherche français ou étrangers, des laboratoires publics ou privés. 


\title{
When instability increases the effectiveness of aid projects
}

\author{
Patrick Guillaumont $^{1}$ and Rachid Laajaj ${ }^{2}$
}

\begin{abstract}
This paper assesses the effect of economic instability on the success of the projects funded by the World Bank, using the outcome of the projects, which is a notation of their overall success determined by the Independent Evaluation Group. It has been argued in macro economic studies that aid effectiveness is higher in vulnerable countries, because it dampens the negative effects of shocks. We show that this finding is not inconsistent with the observation that the success of the projects is lower in an unstable environment. Indeed instability, in particular the instability of exports, harms aid projects as it harms the rest of the economy, while the success of projects decreases when the total amount of aid received increases, due to absorptive capacity limitations. However this decrease is slower when instability is higher, showing a positive effect of aid through its stabilizing impact. We find the same results keeping only the projects funded by non concessionary loans, which suggests that the cushioning effect of aid extends not only to aid funded projects but to whole sets of projects. Corroborating macro economic findings, our results lead to the same conclusion that more aid should be allocated to more vulnerable countries, in spite of the lower success of the projects in an unstable environment: project evaluations cannot include the macro-stabilizing effect of the aid delivered through projects.
\end{abstract}

\section{World Bank Policy Research Working Paper 4034, October 2006}

The Policy Research Working Paper Series disseminates the findings of work in progress to encourage the exchange of ideas about development issues. An objective of the series is to get the findings out quickly, even if the presentations are less than fully polished. The papers carry the names of the authors and should be cited accordingly. The findings, interpretations, and conclusions expressed in this paper are entirely those of the authors. They do not necessarily represent the view of the World Bank, its Executive Directors, or the countries they represent. Policy Research Working Papers are available online at http://econ.worldbank.org.

\footnotetext{
${ }^{1}$ CERDI Université d'Auvergne and CNRS.

${ }^{2}$ CERDI and the World Bank Independent Evaluation Group, (rlaajaj@worldbank.org).

We would like to thank Ajay Chhibber for his helpful comments.
} 


\section{1 - Introduction}

This paper examines at the micro level two issues related to aid effectiveness which have been previously and separately considered at the macro level: whether aid effectiveness increases when receiving countries face exogenous shocks and decreases when the total amount of aid increases. The micro economic data on which the analysis relies are the success of the projects funded by the World Bank.

In the last ten years, a large debate on aid effectiveness has followed the Burnside and Dollar paper (2000) supporting the view that aid has a positive impact on growth on the condition that the country has sound policies and institutions. These results, criticized by many authors, are still the matter of keen debates (Hansen and Tarp, 2001). It has been argued that other features of recipient countries may have a potential impact on aid effectiveness, even more significant than policy and institutions. In particular macro economic studies (Guillaumont and Chauvet, 2001; Chauvet and Guillaumont, 2004) evidence that aid effectiveness, measured by the impact of aid on growth, is higher in vulnerable countries. Following these results, one would expect to find the same evidence at the micro economic level. However most practicians would agree that projects are harder to carry out in an unstable environment which at first sight seems to be in contradiction with the previous findings.

The apparent paradox results from the fact that the stabilizing effect of aid is hardly perceived at a micro economic level. We can consider this effect as a positive externality since each project evaluation does not include the stabilization brought by the project itself, but is affected by the stabilization resulting from the whole amount of aid received by the country. According to the quoted macro economic finding, instability (vulnerability) as such is a negative factor on growth, while aid dampens this effect. Correspondingly, we expect instability to lower the average return to the projects, but all the less that aid is higher.

The results presented in this paper show that the instability of exports harms project outcomes, as it harms the rest of the economy, while the success of the projects decreases with the total amount of aid received, due to absorptive capacity limitations. But we also find that this decrease is slower when instability is higher. For extremely high levels of instability it can even be reversed, leading to an increasing return to aid. Thus the present paper also meets the burning 
question of limited absorptive capacity, which to a large extent is linked to decreasing marginal returns of aid.

Following Kaufmann and Wang (1995), Isham, Kaufmann and Pritchett (1997), Isham and Kaufmann (1999) and Levin and Dollar (2005), we use data from the projects funded by the World Bank and evaluated by the Independent Evaluation Group (IEG) of the World Bank. Whereas these four studies support the view that better policies and institutions result in a higher economic rate of return and a higher probability of success of projects, we provide micro economic evidence on the influence of instability on aid effectiveness.

A main difference between our methodology and that of the authors of the previously mentioned four studies is that they all aggregate project data to the national level to obtain average economic rates of return or rates of success, while we run our regressions at a micro economic level using each project as an observation. This allows us to directly use a larger part of the available information: our explained variable is the outcome rating of the projects which focuses on the achievement of development objectives. Given that the outcome is a six scale notation, ranging from "very unsatisfactory" to "very satisfactory", our econometric model is an ordered logit. The success of each project is explained by the characteristics of the project (sector...), initial characteristic of the countries at project implementation (level of GDP, education, aid or institutions) and average characteristics of the countries during the realization of the project (level of exports, variability of exports...). Nonetheless, as a robustness check, we also aggregate the data to the country-level to confirm that the results are not sensitive to a change in the methodology.

The structure of the paper is as follows. In the next section we examine the consistency between the macro economic finding that aid dampens the negative effects of instability and the micro evidence of a lower decline of the success of aid projects (when aid increases) in an unstable environment: the stabilizing impact of aid is considered as a positive externality of aid projects. In section 3 we present our econometric model of the determinants of the success of projects where the macro economic variables of interest are the instability of exports, the amount of aid, and a variable multiplicative of the two previous ones likely to capture the stabilizing impact of aid. Section 4 is devoted to the estimation of the model and to the presentation of the results, the robustness of which is then checked. 


\section{2 - Aid effectiveness and vulnerability: from the macro to the micro level}

In cross-country studies, Guillaumont and Chauvet $(2001,2004)$ provided evidence that a worse external environment (measured by climatic and trade shocks) increases the impact of aid on growth and Collier and Dehn (2001) found that the adverse effects of an extreme negative export price shock can be mitigated through an increase in aid. Nevertheless, at a micro economic level there is no empirical evidence to support this statement yet. On the contrary, people who carry out development projects would state that instability hinders the success of the projects. After stressing the advantages of a micro economic study, we will analyze the reasons for this apparent paradox.

\section{Benefits from using micro economic data on the success of projects}

Macro economic studies that analyze aid effectiveness through the impact of international aid on growth face some well known difficulties. First, growth is not the only objective of aid. Other objectives, like poverty alleviation or increasing education, could be considered more legitimate, but most of the macro economic studies are limited to the impact of aid on growth because of a lack of other reliable and frequently available indicators of economic development. Now since we have seen that economic instability can increase poverty through growth as well as directly, estimating the cushioning effect of aid only on growth would lead to an underestimation of this effect. Secondly, macro economic studies can usually capture only the short or medium term effects of aid yet we would not expect an education project, for example, to have an impact on growth for many years to come.

To some extent, these difficulties can be avoided using micro economic data. In this paper, our explained variable is the outcome of the projects, based on three criteria: relevance of the objectives, efficacy and efficiency of the projects. The relevance of the projects refers to all the development priorities defined by the receiving country and the World Bank rather than only the impact of aid on economic growth. These data also account for the long term effects of aid since the benefits are actualized for each project. Furthermore the use of a micro economic dependent variable explained by macro-economic variables limits the risk of endogeneity: the risk of reverse causality is reduced if we suppose that a project is usually too small to influence

the characteristics of a country; however, because aid could be correlated with some unobserved variables, the endogeneity of aid has to be tested. 
Nonetheless, as we will see, these advantages come at a cost: not all the effects of aid can be perceived at the project level. This is the reason why the success of projects has to be explained not only by characteristics of the country traditionally included as explanatory variables (such as income per capita or quality of institutions), but also by variables reflecting "external effects" of aid volume on the success of projects, which we now consider.

\section{Taking into account the decreasing returns of aid}

Decreasing returns can be assumed for aid as for other expenditures. However there also could be some threshold below which the marginal return is increasing, giving some legitimacy to the big push thesis. In macro economic works examining the aid and growth relationship, decreasing marginal returns to aid have been examined through a possible negative coefficient on the squared aid level (Collier and Dollar 2001) and have been a matter of debate (Hansen and Tarp, 2001), while few evidence have been made of increasing returns (with the exception of Gomanae et al. 2003 who found the existence of a threshold below which aid would have no effect). In our micro economic study of the determinants of the success of projects, as in Dollar and Levine (2005) decreasing (increasing) returns will be captured through a negative (positive) coefficient of the aid level. Possible thresholds of successively increasing, then decreasing returns could be tested though the coefficients on the level of aid and its square value.

\section{The negative impact of instability evidenced both at the macro and micro level}

There is now a relative consensus about the negative effects of economic instability on growth and poverty reduction. Both aspects are considered in Guillaumont (2006); main evidences on the effects on growth include Ramey and Ramey (1995), Hnathovska and Loayza (2004). At a micro economic level, risk averse agricultural producers might refuse to adopt more profitable but riskier techniques, or can forgo educating their children following a negative shock. At a macro economic level, the main channels through which exogenous sources of economic instability hinders growth include its transmission to the real exchange rate, to public finance, resulting in chronic inflation and public indebtedness, or to the instability of public investment, leading to a lower average rate of return (Guillaumont et al. 1998).

Instability has been found to increase poverty not only through lower growth, but also through its effect on income distribution. (Agenor 2001, Laursen et al. 2004, Guillaumont 2006, Guillaumont and Korachais 2006). In most of these macro economic papers, reference is made to 
the negative effects of shocks on households drawn from a large micro economic literature which emphasizes the direct effects of instability on poverty. Micro studies evidence that low income groups are more exposed than others because their incomes are less diversified; their lower human capital makes mobility across occupations and regions more difficult; their access to capital and financial markets is limited; their dependence on public services (especially health and education) exposes them to fiscal cuts.

\section{The success of projects conditioned on the stabilizing impact of aid}

Since the effect of instability on growth and poverty seems to be unambiguous, it can be expected that if aid has a macro economic stabilizing impact, its effectiveness would be higher in a vulnerable country. In a recent paper Chauvet and Guillaumont (2006) evidence that their previous finding of higher aid effectiveness in more vulnerable countries can be explained by the stabilizing impact of aid. They define "the stabilizing impact of aid" as the difference between the volatility of exports and the volatility of aid plus exports aggregate flow, and show that in most cases aid has a stabilizing impact with regard to exports. This holds even when aid is pro cyclical with regard to exports (positive correlation between the cycle of aid and the cycle of exports) but less volatile than exports (aid is finally stabilizing in about $90 \%$ of cases). As far as the result depends on the relative levels of the volatility of aid and the volatility of exports, when the volatility of exports is high, aid is more likely to be stabilizing.

If aid effectiveness is higher in vulnerable countries then why do these countries have a lower success in development projects? The main reason is that the project evaluations do not include the total impact of the projects and particularly not the stabilizing impact. The latter is not always perceived because the main task of an evaluator is generally confined to appraise whether or not the objectives have been reached at a reasonable cost. To illustrate this, let us imagine the case of an irrigation project targeted to increase agricultural production. A negative shock (climatic, price shock...) can reduce production or its returns and thus harm the project. However the salaries given for the realization of the project might have been particularly beneficial in this period of shortfall, preventing malnutrition or children interrupting their education. These side effects would not be included in the rating if they were not initially part of the objectives.

We can thus divide the total impact of a project into a direct impact and an indirect stabilizing impact. The direct impact, observed by the evaluator, is considered satisfactory when 
the objectives have been achieved. This notation unavoidably reflects the fact that the objectives are less frequently achieved in an unstable environment. The apparent paradox rises from the fact that the stabilizing impact is not perceived at a micro economic level. Each project has a stabilizing impact that affects all the economy through the attenuation of the negative effects of vulnerability as described previously. This "side effect" can be interpreted as a positive externality: not included in the evaluation of the projects, it influences the whole economy, including the other aid projects carried out in the country. The size of this externality is likely to increase with the economic instability of the country.

Since this externality is, by definition, not included in the rating, how can we evaluate it? Each project evaluation does not capture its own externality however it captures the externalities of all the other projects and all aid received by the country that brought an environment more favorable to the achievement of the projects. In vulnerable countries, the existence of a positive externality will thus lead to an increase in the returns to scale that will contrast with the otherwise likely decreasing returns of aid due to the limited absorptive capacity of the receiving country.

\section{3 - Designing a conditional model of the success of the projects}

\section{Combining decreasing returns and cushioning effect of aid at the project level}

Figure 1 summarizes our hypotheses concerning the observed outcome of the projects. It represents the success of the projects depending on the level of Official Development Assistance (ODA) for a vulnerable and a stable country.

Figure 1

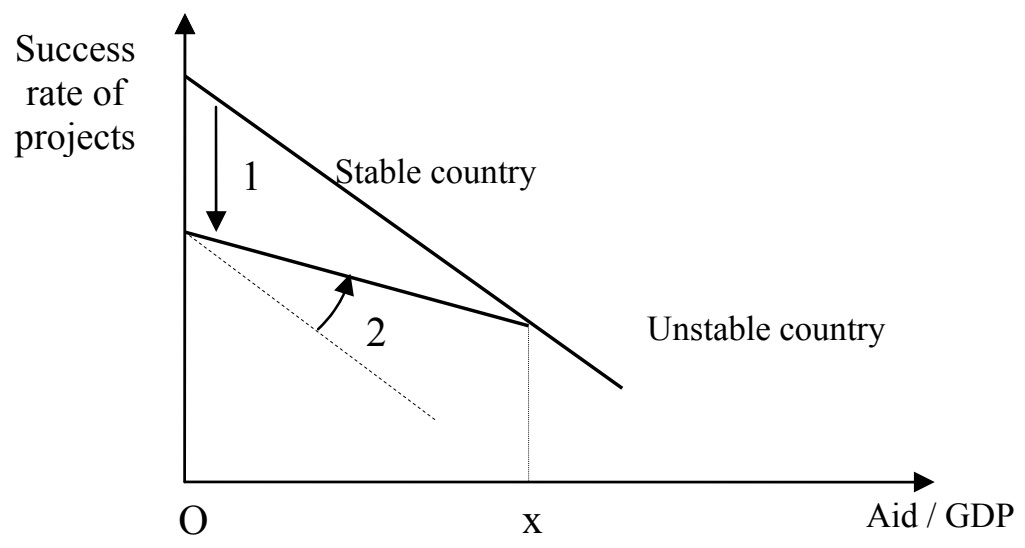


In the stable country, as well in an unstable one, the slope of the curve is negative indicating a limited absorptive capacity: higher amounts of aid are hard to manage and result in a decrease in the success of the projects. Instability has two different effects on the success of the projects, as shown on figure one: the downward shift (1) indicates that vulnerability harms the projects, but the lower slope of the curve (2) represents the cushioning effect of aid. Hence when aid increases, the difference the success of the projects between stable and unstable countries is reduced. The cushioning impact may be so high that it fully compensates for the initially lower success of projects. We shall see that, in the most vulnerable countries, aid might even have increasing returns to scale.

The intersection point ( $\mathrm{x}$ ) is the level of aid that totally compensates for the negative effects of vulnerability so that the chances of success of a project become equal in a stable and an unstable country. Once aid exceeds this point, it could be supposed that a further increase in aid would have a similar impact in the outcome of projects in both countries. Until this point aid increase makes the chances of success of the projects in an unstable country closer to what it is in a stable country due to the cushioning effect of aid.

From these hypotheses, we can deduce our econometric model. The explained variable is the success rate of the projects. We expect that vulnerability is harmful to the projects, the level of aid might also have a negative effect if the country has a limited absorptive capacity, but the multiplicative variable (Aid * Vulnerability) should have a positive impact on the success of the projects showing that when a country is vulnerable, aid dampens the shocks and therefore reduces the negative impact of vulnerability.

\section{Source of the data and measurement of instability}

Our database includes all the projects that have been funded by the World Bank. Among these 6954 projects, 4701 projects started between 1981 and 2002, our period of study. This number goes down to 4597 if we eliminate projects that were dispersed in more than one country. In the main equation, 2894 projects will be preserved after elimination of the projects of which some data are not available. 
In our model, the explained variable is the outcome, which is a measure of project success provided by the IEG. The outcome rating, ranging from "very unsatisfactory" to "very satisfactory", is based on three criteria:

- The relevance of the objectives: Are the objectives of the project consistent with the strategy of the World Bank and the development priorities of the country?

- $\quad$ The efficacy: Were the objectives achieved?

- $\quad$ The efficiency: Were the objectives achieved at least cost compared to alternatives?

This outcome is thus considered as a proxy for the contribution of the project to the development of the receiving country.

For each project, we need to measure an index of instability which reflects the vulnerability of the receiving country for the duration of the project. The variability of exports is used because the cycle of exports is likely to be affected mainly by exogenous shocks such as climatic or price shocks. We first compute an annual index of instability: following the method used by Ramey and Ramey (1995), each year, we calculate the standard deviation of the growth rate of exports during the four last years plus the year in question. Secondly, to obtain the index of instability of each project, we calculate the average of the index for each year during which the project was carried out and multiply it by the logarithm of the average share of exports on GDP during the same period in order to take into account the exposure to shocks.

\section{Descriptive presentation of the data}

A practical way to observe the combined effect of instability and aid on the success of the projects is to use a three dimension diagram. In the next figure, we compare the average success rate $^{3}$ of the projects separated into nine groups. "Low aid" corresponds to the third of projects that have been carried out in countries receiving the lowest level of ODA (less than $1 \%$ of GDP), and "high aid" to the upper third (more than $8 \%$ of GDP). We similarly identified the upper, middle and lower thirds of projects according to the weighted export instability of the receiving country.

\footnotetext{
${ }^{3}$ A project is considered successful if it has been rated at least moderately satisfactory.
} 


\section{Aid compensates instability}

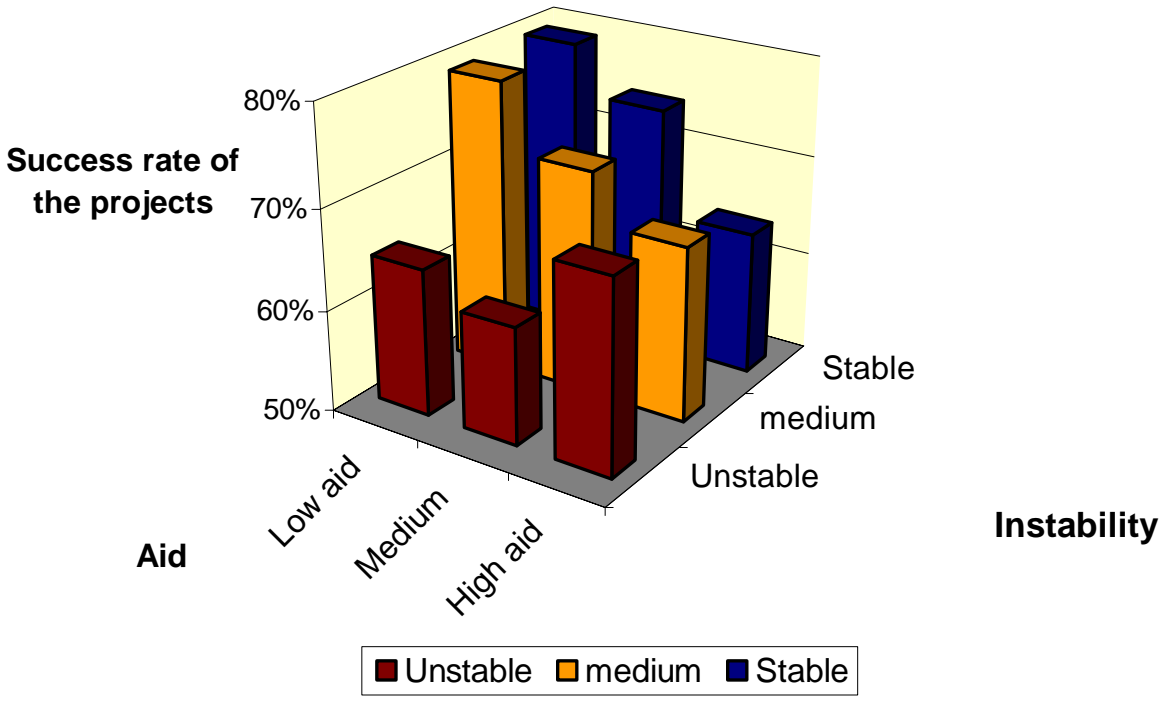

We see in the diagram that for a low level of aid, the average success rate is 15 points higher in a stable country. However, in stable countries, this rate decreases sharply with the level of aid, showing a limited absorptive capacity, while in the most vulnerable group, the success rate seems to increase with the level of aid, or at least remains steady. Accordingly, when aid exceeds $8 \%$ of GDP of the receiving country, the average success rate of the projects is higher in vulnerable countries.

The model to be estimated

The model is the following:

$$
\mathrm{O}=\mathrm{f}(\mathrm{A}, \mathrm{I}, \mathrm{A} \text {. I , Country variables, Project Variables, Year ) }
$$

With:

$$
\begin{aligned}
& \text { - } \quad \mathrm{O}=\text { the outcome of the project } \\
& \text { - } \quad A=\text { the Official Development Assistance as a share of GNI (expected negative } \\
& \text { coefficient, if aid has decreasing returns) } \\
& \text { - } \quad I=\text { the economic instability, measured by the variability of exports weighted } \\
& \text { by the share of exports on GDP (expected negative coefficient) } \\
& \text { A*I }=\text { the dampening effect of aid with regard to instability (expected positive } \\
& \text { coefficient). }
\end{aligned}
$$


- Country variables $=$ the macro economic control variables that are suspected to have an impact on aid effectiveness: $\log$ of the rate of exports during the project ${ }^{4}$, initial level of education and quality of institutions.

- Project Variables $=$ the project related control variables: sector of the project, a dummy for IDA/IBRD, and a dummy for Investment/Adjustment loans.

- Year $=$ year dummies.

All these variables are described in appendix A.

\section{4 -Estimation and main results}

\section{Treating aid endogeneity}

Since the amounts of ODA is not provided randomly, and can be correlated to some unobserved variables, we need to check for the absence of endogeneity of aid. Therefore it is necessary to find instruments which influence the level of aid, but not the success of the projects. When the instruments, as often used in the growth literature, are based on the characteristics of the receiving country (Boone 1996, Burnside and Dollar 2000), they are not satisfactory because they may have a direct impact on the outcome (either the growth rate or the success of the projects). For that reason it is preferable to use instruments based on the characteristics of the donors, as done by Tavares (2003), but with a relatively low explanatory power (similar instrumentation, although augmented, is used by Chauvet and Guillaumont 2006). Still relying on donor variables, we here use another set of instruments, which appears to be efficient.

For each receiving country, Tavares (2003) multiplies the level of aid of the main donors by a geographical and cultural proximity index. We replace his proximity index by another one based on the composition of the donors for each recipient; our instruments are calculated as follow:

- $\quad$ we have selected four main groups of donors ${ }^{5}$;

- we calculate for each combination receiver/group of donors a proximity index equal to the share of aid from this group of donors in the total aid given to the receiver during the last period (four years before);

\footnotetext{
${ }^{4}$ Controlling for the log of the share of exports on GDP is necessary because it has been used to calculate the vulnerability index and we want to isolate the impact of openness from the effect of instability.

${ }^{5}$ The four groups are 1-the IDA 2-the European Community 3-the United States, 4-the four main European donors (France, Germany, United Kingdom and Netherlands).
} 
- the aid of each receiving country is instrumented by four variables (one per group of donors): its proximity index with each group of donors is multiplied by the relative increase in the amount of aid granted by this group of donors during the last four years.

The choice of these instruments relies on two main assumptions:

- the total level of aid granted by the donors is not influenced by the needs of only one receiver, but rather depends on the choices and constraints of the donors;

- when a donor increases its aid, it will tend to give more to those to which it gave during the preceding years.

One thus expects that, ceteris paribus, the aid received by a country increases when the aid given by its main donors increases. This increase can be considered as exogenous. These four instruments (one per group of donors), calculated for each receiver, are used to instrument ODA.

Using these instruments, we carry out the test of Nakamura and Nakamura. In order to avoid a repetition of identical observations when several projects were implemented in the same country during the same period, we use macro economic panel data, pooled by periods of four years from 1980 to 1999 . Our tests confirm the validity of our instruments and the hypothesis of aid exogeneity cannot be rejected ${ }^{6}$.

\section{Main results: the success of aid projects in vulnerable countries}

Regression 1.1 shows the results of the model presented in section 3. This regression will always be referred to as the main regression. Before commenting on our variables of interest, we see that trade and the logarithm of GDP have no significant effect. We also notice that surprisingly the quality of the institutions as measured by the ICRG index has no significant effect on the success of the projects whereas education has a significant positive effect. These results are in contradiction with the findings of Isham and Kaufmann (1999) and Dollar and Levin (2005).

\footnotetext{
${ }^{6}$ In the instrumental equation, the Wald test confirms the joint significance of the instruments at $1 \%$. The residue, introduced in the structural equation, is not significant $(\mathrm{t}$ statistic $=0.79)$. Finally the Sargan test did not reject the validity of our instruments ( $\mathrm{p}$-value $=0.73$ ).
} 
As expected, we see in regression 1.1 that the instability of exports significantly reduces the success of the projects. According to our results, for a country with each variable equal to its average in all the projects, one standard deviation higher on the variability of the exports corresponds to a 10 percentage point lower probability of success ${ }^{7}$.

We also perceive the existence of a limited absorptive capacity of aid since the level of ODA has a negative impact on the success of the projects. However, because the coefficient in front of the interaction term is positive and significant at $1 \%$, we cannot reject our hypothesis that aid has a cushioning impact which increases its effectiveness in vulnerable countries.

Below we use predicted values from the last equation to illustrate the probability of success of the projects related to the level of aid in two countries with identical characteristics (each variable is equal to its average in all the projects), except that one country has a low variability of exports $\left(25^{\text {th }}\right.$ percentile $)$ and the other has a high variability of exports $\left(75^{\text {th }}\right.$ percentile).

\section{Vulnerable countries : lower initial success but higher absorptive capacity}

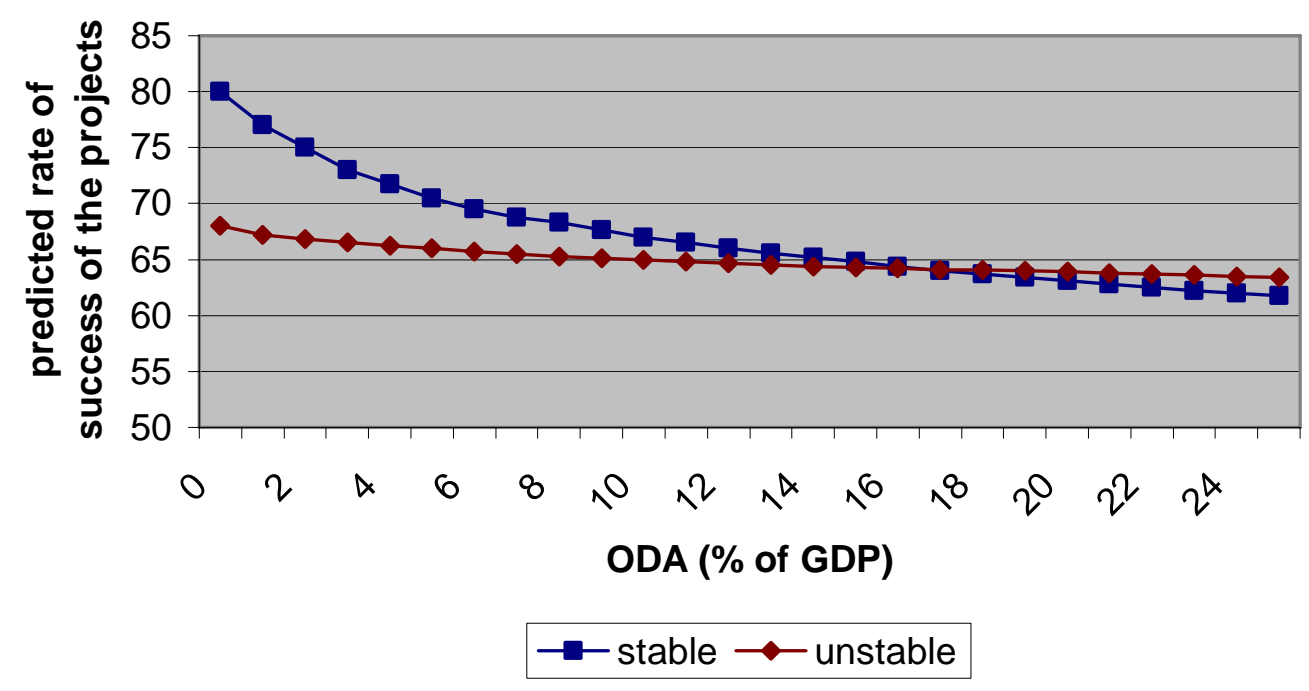

We see that for a low level of ODA, the predicted success of the projects is 12 percentage points lower in the unstable country. This is a micro economic confirmation of the considerable negative impact of instability on the economy.

\footnotetext{
${ }^{7}$ We considered a country receiving a level of aid close to $0 \%$ to exclude the cushioning effect of aid.
} 
Both countries have a limited absorptive capacity of aid, represented by the negative slope of the curve. However in a vulnerable country, the decrease in the return to projects is slower because of the stabilizing effect of aid which partly compensates for the effects of a limited absorptive capacity. According to our results when the ODA reaches $16 \%$ of the GNI of the receiving country, the negative effect of instability is totally compensated for. Hence, each percentage point of ODA on GNI reduces on average $6 \%{ }^{8}$ of the negative effect of vulnerability (regardless of the level of instability).

To better understand these results, we can imagine that an education project is the only project in a very unstable country; then after a negative economic shock, the deterioration of the health status, the infrastructure, and the agricultural productivity will all impede children's education. Conversely, if the country receives enough international aid at the time of the shock, then we can expect that projects will be carried out in most of the sectors and bring a higher macro economic stability, which is beneficial for the government's projects as well as for the country's growth and development.

\section{The cushioning effect of aid tested through the sustainability of projects}

We argue that, in a vulnerable country, the success of the projects increases with the level of ODA because of the cushioning effect of aid. In order to check this hypothesis, we now use the sustainability of the projects instead of the outcome. The sustainability is another project rating provided by the IEG, rating the resilience to risk of net benefit flows over time. If our hypothesis is correct, one would expect that in a vulnerable country, the sustainability is weaker but more ODA results in a higher sustainability. Stated another way, vulnerability and ODA should influence sustainability of the projects in the same way as they influence their outcome; which is what we find in regression 1.2. This corroborates our hypothesis that international aid is more effective in a vulnerable country because of its stabilizing effect.

\section{Results meaningful not only for aid funded projects}

When we say that each percentage point of ODA on GNI reduces on average $6 \%$ of the negative effect of vulnerability, do we mean the negative effect of vulnerability on the World Bank's projects, on aid financed projects, on all the country government's projects or even all the

\footnotetext{
${ }^{8}$ If a level of ODA equal to $16 \%$ of the GNI reduces $100 \%$ of the negative effects of aid, then on average each percentage point of ODA on GNI reduces $6 \%$ of the negative effects of aid.
} 
economy? For a more comprehensive discussion on this question, see Isham Kaufmann and Pritchett (1997) who studied the impact of the quality of country governance on the economic rate of return of the projects. As the authors state, there is very little reason to expect World Bank financed projects to be chosen very differently from other donor agencies, so we can reasonably extend our result to all aid financed projects.

Can we extend our results to all the country government's projects? Fortunately, we can divide the World Bank's funded projects into those funded by the IDA, which are included in international aid, and those funded by the IBRD at the market rate which are not included in international aid. In regression 1.3 and 1.4 we see that, keeping only the IBRD funded projects, the previous results remain steady: aid attenuates the negative effect of instability on the success of the projects. We can thus presume that our results apply not only to aid funded projects, but also to the rest of the country government's projects. Nonetheless, for diverse reasons provided by Isham et al. (1997), there could be a "cream skimming" in the choice of the projects funded by the World Bank. This could lead to a higher average success of the projects, but it would belie our conclusions only if it also leads to projects that are affected very differently by vulnerability and the level of aid.

Can we extend our results to the rest of the economy of the receiving country? It seems very difficult to provide a reliable answer to this question, but we have no reason to expect the stabilizing effect of aid to affect only the public sector. Moreover the combination of the micro economic evidences that we provided in this paper and macro economic evidences (Guillaumont and Chauvet 2001, Chauvet and Guillaumont 2004) seems to confirm the existence of a stabilizing effect of aid that can noticeably improve the welfare of all the receiving country's population.

\section{5 - Additional results and robustness checks}

As these findings have never been observed at a micro economic level before, it is necessary to check the statistical robustness of our results through different tests. In tables 2 to 5 we carry out a number of robustness checks, none of which rejects our main results. 


\section{Removing education and institutions, thus extending the sample}

Although the level of education and the quality of the institutions seem to be key elements that could explain the success of the projects, as a robustness check, we remove them for two reasons. First, they can be channels through which instability influences the outcome of the projects. Instability, if related with previous level of instability, might have reduced the level of education, resulting in a lower success. Excluding this indirect effect would lead to an underestimation of the impact of vulnerability on the project's success. Secondly each one of these variables is not available for every country every year, so removing them adds a lot of observations to our regressions and thus reduces the risk of selection bias.

In regression 2.1 and 2.2, we see that removing the education and institution variables have lessened the significance of the coefficient in front of the multiplicative variable, but generally do not change our main conclusions. We note that institutions are still not significant when we remove the education variable hence the lack of significance of the institution variable was not due to its correlation with education. In regression 2.2, we have 4185 projects, which is more than $90 \%$ of the projects that were carried out in no more than one country during our period of study, we can thus presume that the risk of selection bias is very low.

Some project related control variables have been added to make sure that we compare similar projects in different countries: the sector of the project (one dummy per sector), a dummy for IDA/IBRD, and a dummy for Investment/Adjustment loans. In regression 2.3, we see that removing them has very little impact on our results.

\section{Including other control variables related to instability}

The impact of economic instability on the projects is expected to vary with the source of instability. Hence, an alternative interpretation of our results could be that when economic instability is due to political instability or to the fact that a country is an important oil exporter, the donors would give less aid to these countries considering that these sources of instability are more harmful for the projects than economic instability ${ }^{9}$. This would explain why the coefficient in front of the instability is negative while the coefficient in front of the multiplicative variable is

\footnotetext{
${ }^{9}$ We can expect aid to be less effective in a politically unstable country because of the lack of institution able to make an effective use of aid, and in an important oil exporter because the need for foreign currency would be lower.
} 
positive. Even though our test confirmed the exogeneity of aid; in regression 2.4, we test this interpretation against our first interpretation by adding two control variables: the proportion of years of war in the total number of years in the country during the duration of the project, and the average fuel exports as a percentage of merchandise exports. As expected these two variables have a negative impact on the success of the projects, however they do not noticeably alter the results on the impact of ODA related to vulnerability; thus we cannot reject our first interpretation.

\section{World Bank loans and credits instead of Official Development Assistance}

It might seem inappropriate that we use the ODA to explain the success of projects which are not all part of the ODA: as mentioned before, since the loans granted by the IBRD are at the market rate, they are not included in international aid. This criticism is relevant for the use of ODA as a control variable to estimate the limited absorptive capacity, except if we assume that concessionary loans are in competition with non concessionary loans then a higher level of aid can reduce the marginal return to projects funded by non concessionary loans. However it is less relevant for the multiplicative variable, because we argue that the stabilizing effect of aid should affect not only aid project but also the rest of the economy and especially the government projects.

In regression 3.1 we apply the same model, replacing the ODA by the total amount of the loans provided by the World Bank to the country during the fist year of the project:

$\mathrm{O}=\mathrm{f}(\mathbf{W B}, \mathrm{I}, \mathbf{W B} * \mathbf{I}$, Country variables, Project Variables, Year )

With $\mathrm{WB}=$ the total amount of the loans from the IBRD and IDA to the receiving country

We can see that the total amount of the loans granted by the World Bank has a negative impact on the success of the Bank projects. This result can be interpreted as another symptom of the limited absorptive capacity of capital of the receiving country, but it might also reflect the limited management capacity of the World Bank and its agency in the country. Besides we see that once again, the coefficient in front of the multiplicative variable is significant at one percent, which confirms the existence of a stabilizing effect of aid, higher in more unstable countries. These results mean that even if the World Bank was the only agency that reallocates more 
assistance toward unstable countries, it should be effective because of the stabilizing effect of this external source of funding.

\section{Giving the same weight to each country}

Because the number of projects per country is divided very unequally, one or a few countries could by themselves have a major influence on the results. In order to give the same weight to each country, in regression 3.2 each observation is weighted by $1 / p$; with $p=$ proportion of projects carried out in the country in the total number of projects included in the regression. The results show that giving the same weight to each country does not alter our main conclusions.

\section{Controlling for the non observed heterogeneity of the countries}

Because we need the variance between countries to lead to conclusions about aid effectiveness and aid allocation, we did not use fixed effects in our main regression. Nevertheless our results could be influenced by the unobserved heterogeneity between countries. For this reason, we add fixed effects: in regression 3.3 we can see that our results remain significant and relatively stable when we use only the variance within countries. Therefore our results not only points out that more aid should be given to the most vulnerable countries, but also that more aid should be given to a country when it is exposed to more instability.

\section{Modification of the calculation of the variability of exports}

We now run the same regressions as the main one, except that we change the calculation of the variability of exports. Following Bulir and Hammann (2001, 2003), Pallage and Robe (2001) and Rand and Tarp (2002), and as done in Chauvet and Guillaumont (2006), we use an HP filter $^{10}$ (Hodrick and Prescott, 1997) to extract the trend component of the logarithm of the exports (in constant dollars). The yearly variability of exports is then equal to the average deviation from the trend during each one of the four previous years plus the year in question. Similarly to our first method, the average variability for the duration of the project is weighted by the logarithm of the average share of exports on GDP during the same period to take into account the exposure to shocks.

\footnotetext{
${ }^{10}$ We chose a smoothing parameter of 6.25 following the value recommended by Ravn and Uhlig (2002) on annual data.
} 
In regression 4.1 to 4.4 , we use the new calculation of variability of exports as a measure of economic instability. In the reproduction of the main equation as well as in the robustness checks, the impact of economic instability on the success of the projects is negative, and the coefficient in front of the multiplicative variable is significantly positive. Thus our results are robust to a modification of a measurement of the variability of exports; however, the impact of the stabilizing effect is now smaller: now each percentage point of ODA on GNI reduces on average $3.5 \%$ of the negative effect of vulnerability.

\section{Macro economic regressions}

In this paper, the unit of observation has always been each project funded by the World Bank. We will now aggregate these observations by country and by four year periods to obtain average rate of success of the projects. The explained variable is equal to the average rate of success of all the projects carried out in the country during the period ${ }^{11}$. In regression 5.1 we run the same model as the one of the main equation pooling panel data from 1980 to 1999 with the 55 countries for which the data are available. In the following regression of table 5, we present the results with country fixed effects: we find evidences of the existence of a stabilizing effect of aid with a coefficient in front of the multiplicative variable significant at $5 \%$ and $10 \%$ with fixed effects. We also note that this time, using the same method as Isham and Kaufmann (1999) or Dollar and Levin (2005) we find similar results: the quality of institutions significantly improves the success of the projects.

\footnotetext{
${ }^{11}$ When a project is divided into two or more periods, its rating is divided into these periods proportionally to the duration of the project in each period.
} 


\section{7 - Conclusion}

Some macro economic studies have shown that economic instability increases aid effectiveness or in other words that aid lowers the negative consequences of instability, because it dampens the shocks. This paper brings a micro economic confirmation of these results. It evidences that aid has a stabilizing effect, which is not directly perceived by the evaluators of each project since it cannot be easily observed at a micro economic level. Indeed the vulnerability of a country harms the success of the projects, but this is less when the level of ODA received by the country is high, which leads to the conclusion that aid reduces the negative effects of economic instability. These results substantiate the macro economic findings and provide further support that more aid should be given to vulnerable countries because it can dampen the negative effects of shocks. It can be done by taking into consideration a measure of vulnerability in the criteria used for aid selectivity, as suggested elsewhere (Amprou et al. 2006, Guillaumont 2006).

These results have not been rejected by the various robustness checks that we carried out but the size of the cushioning effect of aid can vary considerably with the choice of the model. Nonetheless, since we provided elements in favor of the idea that this stabilizing effect of aid extends to all the government expenditures and to some extent to the rest of the economy, the stabilizing impact of aid seems far from being negligible.

Our findings also raise the need for further studies on aid effectiveness in vulnerable countries. Because managing projects in an unstable environment is difficult, it is essential to take into consideration the vulnerability of the country during the conception of the projects: for example, some project performance assessment reports of the World Bank (2000) recommend more flexible short-term and small projects and an emphasis on monitoring in unstable countries in order to handle the lack of predictability. More studies may be required on how to conceive and carry out projects adapted to an unstable environment. 


\section{References}

AGENOR P-R. (2001). "Business Cycles, Economic Crises, and the Poor: Testing for Asymmetric Effects”, Policy Research Working Paper 2700. World Bank, Washington, D.C.

AMPROU J., P. GUILLAUMONT, and S. GUILLAUMONT JEANNENEY (2005). “Aid Selectivity According to Augmented Criteria", Working Paper, Agence Française de Développement, Paris.

BOONE P. (1996). "Politics and the Effectiveness of Foreign Aid", European Economic Review, No. 40, p. 289-329.

BULǐ̌ A. and A. J. HAMANN (2001). "How Volatile and Unpredictable Are Aid Flows, and What Are the Policy Implications?” IMF Working Paper 167, October.

BULỉ̌ A. and A. J. HAMANN (2003). "Aid Volatility : An Empirical Assessment", IMF Staff Papers 50(1), p. 64-89.

BURNSIDE C. and D. DOLLAR (2000). “Aid, Policies and Growth”, American Economic Review, No. 90 (4), p. 847-868.

CHAUVET L., and P. GUILLAUMONT (2006). "Aid, Volatility and Growth in Africa" Unpublished, CERDI, Clermont-Ferrand, France.

CHAUVET, L., and P. GUILLAUMONT (2004). "Aid and Growth Revisited: Policy, Economic Vulnerability and Political Instability", In Toward Pro-Poor Policies-Aid, Institutions and Globalization, ed. B. Tungodden, N. Stern, and I. Kolstad. Washington, DC: World Bank/Oxford University Press.

COLLIER P. and J. DEHN (2001). “Aid, Shocks and Growth”, World Bank, Development Research Group, Washington D.C.

COLLIER P. and D. DOLLAR (2002). “Aid Allocation and Poverty Reduction”, European Economic Review, No. 46 (8), p. 1475-1500.

COLLIER P. and J. GUNNING, eds. (1999). "Trade Shocks in Developing Countries: Theory and Evidence". Oxford: Oxford University Press (Clarendon).

DAWE D. (1996). “A New Look at the effects of Export Instability on Investment and Growth", World Development 24(12).

EASTERLY W., M. KREMER, L. PRITCHETT and L.H. SUMMERS (1993). "Good Policy or Good Luck?", Journal of Monetary Economics 32.

GOMANEE K., S. GIRMA and O. MORRISSEY (2003). "Searching for Aid Thresholds effects", CREDIT Research Paper, No. 99 (6), University of Nottingham.

GUILLAUMONT P. and L. CHAUVET (2001). "Aid and Performance: A Reassessment", Journal of Development Studies, No. 37, p. 66-92. 
GUILLAUMONT P. (2006). "Macroeconomic Vulnerability in Low-income Countries and Aid Responses", in Bourguignon F., B. Pleskovic, J Van der Gaag (Eds), Securing Development in an Unstable World, Annual Bank Conference on Development Economics, Europe 2005, Washington, The World Bank, pp 65-108.

GUILLAUMONT P., S. GUILLAUMONT JEANNENEY, and J. F. BRUN (1999). "How Instability Lowers African Growth”, Journal of African Economies 8 (1): 87-107.

GUILLAUMONT P., and C. KORACHAIS. (2006). "Growth Instability against Pro-Poor Growth.” Unpublished, CERDI, Clermont-Ferrand, France.

HANSEN H., and F. TARP (2001). "Aid and Growth Regressions", Journal of Development Economics 64 (2): 547-70.

HNATHOVSKA V., and N. LOAYZA (2004). "Volatility and Growth", World Bank Policy Research Working Paper No. 3184, Washington, DC.

HODRICK, R. J. and PRESCOTT E. C. (1997). "Postwar U.S. Business Cycles: An Empirical Investigation", Journal of Money, Credit, and Banking 29(1), p. 1-16.

ISHAM J. and D. KAUFMANN (1999). "The Forgotten Rationale for Policy Reform: The Productivity of Investment Projects", Quarterly Journal of Economics 114(1), pp. 149-184. February.

ISHAM J., D. KAUFMANN, and L. H. Pritchett (1997). "Civil Liberties, Democracy, and the Performance of Government Projects”, World Bank Economic Review 11(2), pp. 219-242.

KAUFMANN D. and Y. WANG (1995). "Macroeconomic Policies and Project Performance in the Social Sectors: A Model of Human Capital Production and Evidence from LDCs", World Development 23(5), pp. 751-765.

LAURSEN T., and MAHAJAN, S. (2004). "Volatility, Income Distribution, and Poverty", in Aizenman, Joshua and Brian Pinto (eds.).

LEVIN V. and DOLLAR, D., (2005). "Sowing and reaping: institutional quality and project outcomes in developing countries", Policy Research Working Paper Series 3524, The World Bank.

PALLAGE S. and ROBE M. A. (2001). "Foreign Aid and the Business Cycle", Review of International Economics 9(4), p.641-672.

RAMEY G. and V. RAMEY, (1995). "Cross Country Evidence on the Link Between Volatility and Growth", American Economic Review 85(5), 1138-1151.

RAND J. and TARP F. (2002). "Business Cycles in Developing Countries : Are They Different?" World Development 30(12), p. 2071-2088.

RAVN M. O. and UHLIG, H. (2002). "On Adjusting the Hodrick-Prescott Filter for the Frequency of Observations", The Review of Economics and Statistics 84(2), p. 371-380.

TAVARES J. (2003). “Does Foreign Aid Corrupt?” Economic Letters, No. 79, p. 99-106. 
VARANGIS P., AKIYAMA T. and MITCHELL D. (1995). "Managing Commodity Booms and Busts", World Bank Directions in Development.

WORLD BANK. "Shocks and Social Protection: Lessons from the Coffee Crisis in Central America", Latin American and Caribbean Region, forthcoming. 
Table 1: Main Results

\begin{tabular}{lcccc}
\hline & \multicolumn{2}{c}{ All projects } & \multicolumn{2}{c}{ only IBRD } \\
& 1.1 & 1.2 & 1.3 & 1.4 \\
& outcome & sustainability & outcome & sustainability \\
\hline Log ODA (\% of GDP) & -0.3923 & -0.333 & -0.819 & -0.567 \\
& $(0.009)^{* * *}$ & $(0.028)^{* *}$ & $(0.000)^{* * *}$ & $(0.008)^{* * *}$ \\
Variability of Exports & -0.0167 & -0.014 & -0.023 & -0.02 \\
& $(0.000)^{* * *}$ & $(0.022)^{* *}$ & $(0.000)^{* * *}$ & $(0.002)^{* * *}$ \\
ODA * exports variability & $\mathbf{0 . 0 0 5 8}$ & $\mathbf{0 . 0 0 4}$ & $\mathbf{0 . 0 1 3}$ & $\mathbf{0 . 0 0 7}$ \\
& $\mathbf{( 0 . 0 0 1 ) ^ { * * * }}$ & $\mathbf{( 0 . 0 7 2})^{*}$ & $\mathbf{( 0 . 0 0 1 ) ^ { * * * }}$ & $\mathbf{( 0 . 0 8 5})^{*}$ \\
Log exports (\% of GDP) & -0.0538 & -0.089 & 0.128 & 0.142 \\
& $(0.740)$ & $(0.667)$ & $(0.522)$ & $(0.572)$ \\
Log GDP/capita & -0.1142 & -0.135 & -0.116 & -0.169 \\
Institutions (ICRG) & $(0.515)$ & $(0.557)$ & $(0.461)$ & $(0.480)$ \\
& 0.0633 & 0.219 & 0.055 & 0.295 \\
Education & $(0.576)$ & $(0.076)^{*}$ & $(0.686)$ & $(0.044)^{* *}$ \\
& 0.1661 & 0.171 & 0.129 & 0.167 \\
Micro control variables & $(0.014)^{* *}$ & $(0.063)^{*}$ & $(0.075)^{*}$ & $(0.100)$ \\
Year dummies & $\mathrm{Y}$ & $\mathrm{Y}$ & $\mathrm{Y}$ & $\mathrm{Y}$ \\
\hline Observations & $\mathrm{Y}$ & $\mathrm{Y}$ & $\mathrm{Y}$ & $\mathrm{Y}$ \\
Pseudo R-squared & 2894 & 2696 & 1772 & 1656 \\
\hline
\end{tabular}

Robust $\mathrm{p}$ values in parentheses

* significant at $10 \%$;* significant at $5 \%$;** significant at $1 \%$ 
Table 2: Robustness checks, less and more control variables

\begin{tabular}{|c|c|c|c|c|}
\hline & $\begin{array}{c}2.1 \\
\text { outcome }\end{array}$ & $\begin{array}{c}2.2 \\
\text { outcome }\end{array}$ & $\begin{array}{c}2.3 \\
\text { outcome }\end{array}$ & $\begin{array}{c}2.4 \\
\text { outcome }\end{array}$ \\
\hline $\log$ ODA ( $\%$ of GDP) & $\begin{array}{c}-0.4511 \\
(0.004)^{* * *}\end{array}$ & $\begin{array}{l}-0.201 \\
(0.142)\end{array}$ & $\begin{array}{c}-0.378 \\
(0.010)^{* *}\end{array}$ & $\begin{array}{c}-0.473 \\
(0.002)^{* * * *}\end{array}$ \\
\hline Variability of Exports & $\begin{array}{c}-0.0172 \\
(0.000)^{* * *}\end{array}$ & $\begin{array}{c}-0.006 \\
(0.014)^{* *}\end{array}$ & $\begin{array}{c}-0.016 \\
(0.000)^{* * *}\end{array}$ & $\begin{array}{c}-0.016 \\
(0.000)^{* * *}\end{array}$ \\
\hline ODA * exports variability & $\begin{array}{c}0.0057 \\
(0.000)^{* * *}\end{array}$ & $\begin{array}{c}0.001 \\
(0.028)^{* *}\end{array}$ & $\begin{array}{c}0.005 \\
(0.001)^{* * *}\end{array}$ & $\begin{array}{c}0.004 \\
(0.028)^{* *}\end{array}$ \\
\hline Log exports ( $\%$ of GDP) & $\begin{array}{l}0.0136 \\
(0.905)\end{array}$ & $\begin{array}{c}0.002 \\
(0.984)\end{array}$ & $\begin{array}{l}-0.027 \\
(0.857)\end{array}$ & $\begin{array}{c}0.009 \\
(0.945)\end{array}$ \\
\hline Log GDP/capita & $\begin{array}{l}0.0004 \\
(0.998)\end{array}$ & $\begin{array}{c}0.077 \\
(0.467)\end{array}$ & $\begin{array}{c}-0.07 \\
(0.705)\end{array}$ & $\begin{array}{l}-0.221 \\
(0.116)\end{array}$ \\
\hline Institutions (ICRG) & $\begin{array}{c}0.072 \\
(0.507)\end{array}$ & & $\begin{array}{c}0.059 \\
(0.613)\end{array}$ & $\begin{array}{c}0.03 \\
(0.783)\end{array}$ \\
\hline Education & & & $\begin{array}{c}0.158 \\
(0.020)^{* *}\end{array}$ & $\begin{array}{c}0.142 \\
(0.013)^{* *}\end{array}$ \\
\hline War & & & & $\begin{array}{c}-0.574 \\
(0.000)^{* * *}\end{array}$ \\
\hline Oil exports (\% of exports) & & & & $\begin{array}{c}-0.006 \\
(0.086)^{*}\end{array}$ \\
\hline Micro control variables & Y & $\mathrm{Y}$ & $\mathbf{N}$ & $\mathrm{Y}$ \\
\hline Year dummies & $\mathrm{Y}$ & $\mathrm{Y}$ & $\mathrm{Y}$ & $\mathrm{Y}$ \\
\hline Observations & 3377 & 4185 & 2933 & 2482 \\
\hline Pseudo R-squared & 0.026 & 0.021 & 0.022 & 0.037 \\
\hline
\end{tabular}

Robust $\mathrm{p}$ values in parentheses

* significant at $10 \%$;* significant at $5 \%$;** significant at $1 \%$ 
Table 3: More robustness checks, World Bank loans, weights and fixed effects

\begin{tabular}{|c|c|c|c|}
\hline & $\begin{array}{c}3.1 \\
\text { outcome }\end{array}$ & $\begin{array}{c}3.2 \\
\text { outcome }\end{array}$ & $\begin{array}{c}3.3 \\
\text { outcome }\end{array}$ \\
\hline Log ODA ( $\%$ of GDP) & & $\begin{array}{c}-0.307 \\
(0.053)^{*}\end{array}$ & $\begin{array}{c}-0.315 \\
(0.092)^{*}\end{array}$ \\
\hline Variability of Exports & $\begin{array}{c}-0.029 \\
(0.000) * * *\end{array}$ & $\begin{array}{c}-0.022 \\
(0.000)^{* * *}\end{array}$ & $\begin{array}{c}-0.013 \\
(0.000)^{* * *}\end{array}$ \\
\hline ODA * exports variability & & $\begin{array}{c}0.008 \\
(0.000)^{* * *}\end{array}$ & $\begin{array}{c}0.005 \\
(0.004)^{* * *}\end{array}$ \\
\hline Log World Bank loans (\% of GDP) & $\begin{array}{c}-0.8067 \\
(0.000) * * *\end{array}$ & & \\
\hline WB loans * exports Variability & $\begin{array}{c}0.0091 \\
(0.000) * * *\end{array}$ & & \\
\hline Log exports ( $\%$ of GDP $)$ & $\begin{array}{l}0.0271 \\
(0.853)\end{array}$ & $\begin{array}{c}-0.291 \\
(0.091)^{*}\end{array}$ & $\begin{array}{l}-0.599 \\
(0.111)\end{array}$ \\
\hline Log GDP/capita & $\begin{array}{l}-0.1631 \\
(0.166)\end{array}$ & $\begin{array}{c}0.017 \\
(0.920)\end{array}$ & $\begin{array}{l}-0.629 \\
(0.108)\end{array}$ \\
\hline Institutions (ICRG) & $\begin{array}{l}0.0063 \\
(0.950)\end{array}$ & $\begin{array}{c}0.253 \\
(0.011)^{* *}\end{array}$ & $\begin{array}{c}-0.304 \\
(0.008)^{* * *}\end{array}$ \\
\hline Education & $\begin{array}{c}0.1623 \\
(0.024)^{* *}\end{array}$ & $\begin{array}{c}0.16 \\
(0.011)^{* *}\end{array}$ & $\begin{array}{c}0.266 \\
(0.095)^{*}\end{array}$ \\
\hline Weighted $^{12}$ & $\mathrm{~N}$ & $\mathbf{Y}$ & $\mathrm{N}$ \\
\hline Country dummies & $\mathrm{N}$ & $\mathrm{N}$ & $\mathbf{Y}$ \\
\hline Micro control variables & $\mathrm{Y}$ & $\mathrm{Y}$ & $\mathrm{Y}$ \\
\hline Year dummies & $\mathrm{Y}$ & $\mathrm{Y}$ & $\mathrm{Y}$ \\
\hline Observations & 2814 & 2894 & 2894 \\
\hline Pseudo R-squared & 0.037 & 0.056 & 0.068 \\
\hline
\end{tabular}

Robust $p$ values in parentheses

* significant at $10 \% ; *$ significant at $5 \% ; * *$ significant at $1 \%$

\footnotetext{
${ }^{12}$ In regression 3.2 , each project is weighted by $1 / \mathrm{p}$, with $\mathrm{p}=$ proportion of projects carried out in the same country in the total number of projects included in the regression.
} 
Table 4: More robustness checks, variability of exports measured using H-P filter

\begin{tabular}{lcccc}
\hline & 4.1 & 4.2 & 4.3 & 4.4 \\
& outcome & sust & outcome & outcome \\
\hline Log ODA (\% of GDP) & -0.2279 & -0.224 & 0.023 & -0.389 \\
& $(0.122)$ & $(0.207)$ & $(0.878)$ & $(0.096)^{*}$ \\
Variability of Exports (HP) & -0.4349 & -0.313 & -0.365 & -0.126 \\
& $(0.002)^{* * *}$ & $(0.011)^{* *}$ & $(0.004)^{* * *}$ & $(0.337)$ \\
ODA * exports variability & $\mathbf{0 . 1 2 8 2}$ & $\mathbf{0 . 0 7 3}$ & $\mathbf{0 . 1 1 5}$ & $\mathbf{0 . 0 9 4}$ \\
& $\mathbf{( 0 . 0 0 1 ) ^ { * * * }}$ & $\mathbf{( 0 . 0 3 2 ) ^ { * * }}$ & $\mathbf{( 0 . 0 0 0})^{* * *}$ & $(\mathbf{0 . 0 1 4})^{* *}$ \\
Log exports (\% of GDP) & 0.151 & 0.086 & -0.139 & -0.913 \\
& $(0.483)$ & $(0.749)$ & $(0.569)$ & $(0.016)^{* *}$ \\
Log GDP/capita & -0.182 & -0.201 & -0.084 & -0.637 \\
& $(0.143)$ & $(0.266)$ & $(0.578)$ & $(0.085)^{*}$ \\
Institutions (ICRG) & 0.0349 & 0.194 & 0.162 & -0.401 \\
& $(0.750)$ & $(0.099)^{*}$ & $(0.110)$ & $(0.002)^{* * *}$ \\
Education & 0.1807 & 0.162 & 0.201 & 0.179 \\
& $(0.015)^{* *}$ & $(0.110)$ & $(0.012)^{* *}$ & $(0.313)$ \\
Weighted ${ }^{13}$ & $\mathrm{~N}$ & $\mathrm{~N}$ & $\mathbf{Y}$ & $\mathrm{N}$ \\
Country dummies & $\mathrm{N}$ & $\mathrm{N}$ & $\mathrm{N}$ & $\mathbf{Y}$ \\
Micro control variables & $\mathrm{Y}$ & $\mathrm{Y}$ & $\mathrm{Y}$ & $\mathrm{Y}$ \\
Year dummies & $\mathrm{Y}$ & $\mathrm{Y}$ & $\mathrm{Y}$ & $\mathrm{Y}$ \\
\hline Observations & 2664 & 2488 & 2664 & 2664 \\
Pseudo R-squared & 0.026 & 0.021 & 0.044 & 0.068 \\
\hline
\end{tabular}

Robust $\mathrm{p}$ values in parentheses

$*$ significant at $10 \% ; *$ significant at $5 \% ; * *$ significant at $1 \%$

\footnotetext{
${ }^{13}$ In regression 4.3 , each project is weighted by $1 / \mathrm{p}$, with $\mathrm{p}=$ proportion of projects carried out in the same country in the total number of projects included in the regression.
} 
Table 5: More robustness checks, macroeconomic regressions

\begin{tabular}{lcc}
\hline & 5.1 & 5.2 \\
& outcome & outcome \\
\hline Log ODA (\% of GDP) & -0.0417 & -0.0192 \\
& $(0.251)$ & $(0.701)$ \\
Variability of exports & -0.003 & -0.0021 \\
& $(0.005)^{* * *}$ & $(0.018)^{* *}$ \\
ODA * exports variability & $\mathbf{0 . 0 0 2 4}$ & $\mathbf{0 . 0 0 1 4}$ \\
& $\mathbf{( 0 . 0 1 7})^{* *}$ & $\mathbf{( 0 . 0 7 3})^{*}$ \\
Log exports (\% of GDP) & -0.0003 & 0.0348 \\
& $(0.993)$ & $(0.709)$ \\
Log GDP/capita & -0.0018 & -0.0743 \\
& $(0.961)$ & $(0.396)$ \\
Education & 0.0239 & 0.0266 \\
& $(0.103)$ & $(0.484)$ \\
Institutions (ICRG) & 0.0464 & -0.029 \\
& $(0.020)^{* *}$ & $(0.275)$ \\
Country fixed effect & $\mathrm{N}$ & $\mathbf{Y}$ \\
Period fixed effect & $\mathrm{Y}$ & $\mathrm{Y}$ \\
\hline Observations & 240 & 240 \\
R-squared & 0.211 & 0.151 \\
\hline
\end{tabular}

Robust $\mathrm{p}$ values in parentheses

$*$ significant at $10 \%$;* significant at $5 \%$;** significant at $1 \%$ 


\section{Appendix A: Variables description and sources}

\begin{tabular}{|c|c|c|}
\hline Variable & Description & Source \\
\hline outcome & $\begin{array}{l}\text { Notation rating the extent to which the project's major relevant objectives were } \\
\text { achieved, or are expected to be achieved, efficiently. It is a } 6 \text { scale rating ranging } \\
\text { from very unsatisfactory to very satisfactory. }\end{array}$ & IEG \\
\hline sustainability & $\begin{array}{l}\text { Notation rating the resilience to risk of net benefits flows over time. It is a } 5 \text { scale } \\
\text { rating ranging from highly unlikely to highly likely. }\end{array}$ & IEG \\
\hline $\begin{array}{l}\text { Log ODA }(\% \text { of } \\
\text { GDP })\end{array}$ & $\begin{array}{l}\text { Log of Official Development Assistance during the first year of implementation of } \\
\text { the project (\% of GDP). }\end{array}$ & WDI \\
\hline $\begin{array}{l}\text { Variability of } \\
\text { exports }\end{array}$ & $\begin{array}{l}\text { For each year, we calculate the standard deviation of the growth rate of exports } \\
\text { during the four last years plus the year in question. We then calculate the average } \\
\text { of this standard deviation for each year during which the project was carried out } \\
\text { and multiply it by the log of one plus the average share of exports on GDP during } \\
\text { the same period. }\end{array}$ & $\begin{array}{l}\text { Author's } \\
\text { calculations }\end{array}$ \\
\hline $\begin{array}{l}\text { Variability of } \\
\text { Exports (HP) }\end{array}$ & $\begin{array}{l}\text { For each year, we calculate the average deviation from the trend (given by the } \\
\text { Hodrick-Prescott filter on the log of the exports) during each one of the four } \\
\text { previous years plus the year in question. Identically, the average variability for the } \\
\text { duration of the project is weighted by the logarithm of one plus the average share } \\
\text { of exports on GDP during the same period. }\end{array}$ & $\begin{array}{l}\text { Author's } \\
\text { calculations }\end{array}$ \\
\hline $\begin{array}{l}\text { Log exports }(\% \\
\quad \text { of GDP })\end{array}$ & $\begin{array}{l}\text { Log of one plus the average level of Exports of goods and services for the duration } \\
\text { of the project ( } \% \text { of GDP). }\end{array}$ & WDI \\
\hline Log GDP/capita & $\begin{array}{l}\text { Log of the Gross Domestic Product during the first year of implementation of the } \\
\text { project (constant } 1995 \text { US\$). }\end{array}$ & WDI \\
\hline $\begin{array}{l}\text { Institutions } \\
\text { (ICRG) }\end{array}$ & $\begin{array}{l}\text { Average of the indices of corruption, bureaucratic quality and rule of law (each } \\
\text { one rated from one to six) during the first year of implementation of the project. A } \\
\text { high value corresponds to a better quality of institutions. }\end{array}$ & $\begin{array}{l}\text { ICRG } \\
\text { International } \\
\text { Country Risk } \\
\text { Guide } \\
\end{array}$ \\
\hline Education & $\begin{array}{l}\text { Average schooling years in the total population during the first year of } \\
\text { implementation of the project. }\end{array}$ & $\begin{array}{l}\text { Barro \& Lee } \\
2000\end{array}$ \\
\hline War & $\begin{array}{l}\text { The proportion of years of war in the total number of years in the country for the } \\
\text { duration of the project. }\end{array}$ & CERDI \\
\hline $\begin{array}{l}\text { Oil exports }(\% \text { of } \\
\text { exports })\end{array}$ & $\begin{array}{l}\text { Average fuel exports as a percentage of merchandised exports for the duration of } \\
\text { the project. }\end{array}$ & WDI \\
\hline $\begin{array}{l}\text { Log World Bank } \\
\text { loans }(\% \text { of GDP) }\end{array}$ & $\begin{array}{l}\text { Loans and credits from the IBRD (International Bank for Reconstruction and } \\
\text { Development) and IDA (International Development Association) during the first } \\
\text { year of implementation of the project (\% of GDP). }\end{array}$ & WDI \\
\hline $\begin{array}{l}\text { Micro economic } \\
\text { control variables }\end{array}$ & $\begin{array}{l}\text { Those variables are directly related to the project. We use } 3 \text { kinds of micro } \\
\text { economic control variables: } \\
\text { - one dummy for each sector; } \\
\text { - a dummy equal to } 1 \text { if it is an investment project and } 0 \text { for an adjustment } \\
\text { project; } \\
\text { - a dummy equal to } 1 \text { when the project is funded by IDA and } 0 \text { if it is } \\
\text { funded by IBRD. }\end{array}$ & IEG \\
\hline
\end{tabular}

